\title{
A STUDY OF ANAEMIA AMONG FEMALES OF REPRODUCTIVE AGE GROUP AT A TERTIARY HOSPITAL IN NORTH INDIA
}

\author{
Vatsala Kishore1, Neeraj Kumar Singh ${ }^{2}$
}

${ }_{1}^{1}$ Assistant Professor, Department of Pathology, Heritage Institute of Medical Sciences, Varanasi, Uttar Pradesh, India. ${ }^{2}$ Assistant Professor, Department of Pathology, Heritage Institute of Medical Sciences, Varanasi, Uttar Pradesh, India.

\section{ABSTRACT}

\section{BACKGROUND}

Anaemia has emerged as a major health problem affecting the females in childbearing age group, especially in developing nations like India.1,2 It is of various types, but the most common is iron deficiency anaemias caused due to low iron intake which affects children and pregnant and lactating women. ${ }^{3}$ Study of stained peripheral blood smears and data obtained from haematological cell counter render so much information that a tentative diagnosis can be reached in most of the patients without special tests being done. ${ }^{4}$

The aim of this test was to evaluate the pattern of anaemia among females in childbearing age group in a tertiary care hospital of Varanasi, Uttar Pradesh and evaluate haematological parameters of various types of anaemia among these females.

\section{MATERIALS AND METHODS}

This is a descriptive study. 100 female patients of age between 15-49 years with haemoglobin values less than 12 gm were included in this study. Haematological parameters were obtained on processing the blood samples on electronic cell counter. The values of MCV, MCH, MCHC, red cell distribution width, PCT, reticulocytes and haemoglobin were analysed and correlated.

\section{RESULTS}

The mean age of the women in our observation was 29.3 years. Out of 100 cases studied 40 were categorised as mild anaemia, 41 as moderate anaemia and 19 as severe anaemia. The predominant anaemia was nutritional, mostly belonging to iron deficiency anaemia, others being B12 or folate deficiency and anaemia of chronic diseases/ chronic inflammation.

\section{CONCLUSION}

A detailed basic study of the haematological parameters of anaemia can help us reach the cause, type, severity and forms of haematological disorders without further investigations. This study also emphasises the need of iron supplementation for the females during reproductive age group.

\section{KEY WORDS}

Reproductive Age, Females, MCV, MCH, MCHC.

HOW TO CITE THIS ARTICLE: Kishore V, Singh NK. A study of anaemia among females of reproductive age group at a tertiary hospital in North India. J. Evolution Med. Dent. Sci. 2018;7(26):3067-3070, DOI: 10.14260/jemds/2018/688

\section{BACKGROUND}

Anaemia is a global health problem of the developing countries and it most commonly affects the women of reproductive age groups. From functional point of view, anaemia occurs when the reduced red blood cell count is unable to properly supply the oxygen to peripheral tissues. ${ }^{5}$ The nutritional anaemia is a serious problem in pregnancy affecting $60 \%-70 \%$ of pregnant women. This causes a significant adverse impact on health of foetus as well as mother. ${ }^{4}$ According to the WHO, the magnitude of anaemias in pregnancy within females is $14 \%$ in the developed and $51 \%$ in the developing countries like India. As a result, about $1 / 3^{\text {rd }}$ of global population is anaemic. The females of reproductive age group become specifically vulnerable to anaemia, not only because of poor intake but also due to

'Financial or Other Competing Interest': None.

Submission 10-05-2018, Peer Review 08-06-2018,

Acceptance 15-06-2018, Published 25-06-2018.

Corresponding Author:

Dr. Neeraj Kumar Singh,

Assistant Professor, Department of Pathology,

Heritage Institute of Medical Sciences,

NH2, Bypass, Bhadwar, Varanasi-221311,

Uttar Pradesh, India.

E-mail:dmpdcc84@gmail.com

DOI: $10.14260 /$ jemds $/ 2018 / 688$ blood loss during menstrual cycle and the burden of pregnancy and lactation. This is added on by the hookworm infestation. There is also a decrease in iron absorption during pregnancy due to decreased hydrochloric acid secretion. ${ }^{6}$ As there are no conclusive results and data available in India, especially in Eastern UP regarding the magnitude of anaemia, we have tried to study the distribution pattern of anaemia among the females of childbearing age in the region of Varanasi.

\section{MATERIALS AND METHODS}

This is a descriptive study. A total of 100 females of reproductive age group were studied at a tertiary health care hospital in Varanasi. All females in reproductive age group (16 - 50 years) having $\mathrm{Hb}$ less than $12 \mathrm{gm} \%$ were included in the study. Then the blood sample from each female was drawn for the necessary haematological investigations. They were made to sit comfortably and under all aseptic precautions with the help of a disposable syringe $3 \mathrm{~mL}$ of blood sample was taken from the cubital vein after applying the tourniquet above. A drop of blood from the syringe was put on the glass slide and with the help of another slide a smear was made which was then air dried. The rest of the sample was transferred to an EDTA coated vacutainer tube after labelling it with the identification data of the female. The tube was then shaken well, so that the blood mixes well with 
the EDTA to avoid its clotting. The slides were stained with the Leishman stain, after which they were studied for peripheral blood picture to see the morphological type of anaemia i.e. microcytic hypochromic, macrocytic normochromic, normocytic normochromic, combined morphology or any other. These samples were also analysed on electronic 5 part cell counter and all haematological parameters like MCV, MCH, MCHC, RDW etc. were noted. Automated cell counter works on the principle of impedance method (also known as Coulter's method), whereby it counts and sizes cells by identifying and evaluating changes in the impedance when a particle in the conductive liquid passes through a small aperture. ${ }^{7}$ The blood samples were shaken thoroughly and then tested. The detailed smear report was prepared which included differential count, platelet adequacy and RBC morphology.

All the data thus collected was compiled, tabulated and statistically analysed. The analysis was done using standard and appropriate statistical techniques like percentages using SPSS version 21 software.

\section{RESULTS}

The various haematological parameters, reticulocyte count and peripheral blood smear picture was studied in each of the 100 cases of anaemia in women in childbearing age group.

The mean age of women in our study was 29.3 years with minimum age of 16 years and maximum age of 48 years. The cases were categorised into 3 categories.

Mild anaemia (Hb 10 - 12 gm\%), Moderate anaemia (7 $9.9 \mathrm{gm} \%)$ and Severe anaemia ( $\mathrm{Hb}<7 \mathrm{gm} \%)^{7}$

Out of 100 cases 40 were of mild anaemia, 41 of moderate anaemia and 19 were of severe anaemia.

In all these types, total count and platelets were normal. Cases of severe anaemia were more in the age group of 20 35 years.

Using the Pearson correlation coefficient test, it was found that there was positive association between $\mathrm{Hb}$ and blood cell indices like PCV, MCV, MCH and MCHC.

In our study MCV was normal in 20 cases, decreased in 15 cases and increased in 5 cases of mild anaemia. In cases of moderate anaemia was normal in 17 cases, decreased in 20 cases and increased in 4 cases. In cases of severe anaemia was normal in 5 cases, decreased in 10 cases and increased in 4 cases (Table 1 ).

In cases of mild anaemia 27 cases had decreased MCH, 10 cases had normal MCH and 3 had increased MCH. In cases of moderate anaemia was normal in 19 cases and decreased in 22 cases. In cases of severe anaemia was normal in 1 case, decreased in 14 cases and increased in 4 cases (Table 1).

In cases of mild anaemia, MCHC was decreased in 5 cases and normal in 35 cases. In moderate anaemia, MCHC was decreased in 40 cases and normal in 1 case. In severe anaemia, MCHC was decreased in 13 cases, normal in 5 cases and increased in only 1 case (Table 1 ).

Reticulocyte count was normal in 16 cases and low in 24 cases of mild anaemia. In moderate anaemia retic count was normal in 29 cases, low in 1 case and increased in 11 cases. In severe anaemia it was normal in 12 cases, low in 2 cases and increased in 5 cases (Table 1).

RDW was normal in 10 cases, increased in 29 cases and decreased in 1 case of mild anaemia. RDW was increased in 38 cases, normal in 2 cases and decreased in 1 case of moderate anaemia. In case of severe anaemia, RDW was normal in 1 case, decreased in 1 case and increased in 17 cases (Table 1).

RBC count was normal or decreased in all cases of anaemia.

We used improved classification of anaemia by MCV and RDW by David Bessman et $\mathrm{al}^{4}$ and observed that-

In cases of mild anaemia ( $\mathrm{Hb} 10$ - $12 \mathrm{gm} / \mathrm{dL}$ ): Normocytic, homogeneous (MCV normal, RDW normal)- 24 cases; Normocytic, heterogeneous (MCV normal, RDW high)- 2 cases; Microcytic, homogeneous (MCV- low, RDW- normal)zero cases; Microcytic, Heterogeneous (MCV- low, RDWhigh)- 23 cases; Macrocytic with normal RDW- 1 case.

In cases of moderate anaemia (Hb- 7 - $10 \mathrm{gm} / \mathrm{dL}$ ): Normocytic, homogeneous- 12 cases; Normocytic, heterogeneous- 5 cases; Microcytic, heterogeneous- 20 cases; Macrocytic with raised RDW- 4 cases.

In cases of severe anaemia $(\mathrm{Hb}<7 \mathrm{gm} / \mathrm{dL})$ : Normocytic, homogeneous- 7 cases; Normocytic, heterogeneous- 1 case; Microcytic, homogeneous- 0 cases; Microcytic, heterogeneous- 10 cases; Macrocytic with raised RDW- 1 case.

\section{DISCUSSION}

There have been many studies about the distribution and prevalence of anaemia in the world, but very few studies are conducted for study of nutritional anaemias among women of reproductive age group. Little data is available about the distribution pattern of anaemia in women in eastern UP. The studies so far have emphasised over the anaemias in adolescents and school children. As enough data is not available about the nutritional status of the women of reproductive age, living in the nearby rural areas who rarely visit the hospital for regular check-ups, the assessment of $\mathrm{RBC}$ helps in identifying the causative disorders along with the diagnosis of anaemia. ${ }^{7}$

With peripheral smear examination, RBC morphology is assessed, and the blood cell indices are assessed by quantitative methods.

Both of these help in reaching to a differential diagnosis and rules out the need of unnecessary special tests. ${ }^{5}$

Haematology cell counters have improved the accuracy and precision along with reduction of subjective errors. ${ }^{8}$

We studied 100 cases and categorised them on the basis of $\mathrm{Hb}$ as mild (10 - $12 \mathrm{gm} / \mathrm{dL})$, moderate $(7-9.9 \mathrm{gm} / \mathrm{dL})$ and severe $(7 \mathrm{gm} / \mathrm{dL})$ using WHO classification system.7,9 Majority of the cases were in the age group of 20 - 35 years, which is an active reproductive life in the developing countries. This correlated with the studies by Rairikar,4 BC Mehta ${ }^{10}$ and NFHS-3 survey. ${ }^{11}$ The higher cases of anaemia in this age group could be due to nutritional disorders, early age at pregnancies and many other gynaecological problems. ${ }^{4}$

In the present study $45 \%$ of patients had reduced MCV, $42 \%$ had normal MCV and 13\% had increased MCV. MCV values were lowest in case of severe anaemia. $\mathrm{MCH}$ values also showed a similar pattern.

In this study $47 \%$ females had increased RDW, $3 \%$ had lower RDW and 50\% had normal RDW. RDW was comparatively higher in women with severe anaemia. Similar findings were observed in studies by Rairikar, ${ }^{4}$ Vishwanath ${ }^{12}$ and Carmen et al.13 
According to Ernest Beutler et al, ${ }^{14}$ study of blood cell indices were superior to examination of stained smears in mildly anaemic patients. The improved classification of anaemia by Bassman et $\mathrm{al}^{4}$ established a useful differential diagnosis of RBC disorders (Table 2).

Using this classification described by Bessman, 1553 cases out of 100 cases showed reduced MCV with increased RDW. However, RBC and Reticulocyte Count were found to be normal. So, most of these cases were most probably of the Iron deficiency anaemia.

8 of the cases showed normocytic heterogeneous picture, i.e. MCV normal, RDW high. As RBC count, Reticulocyte Count were also normal with normal RBC's and WBC's, the most common cause here could be mixed deficiency or early folate or iron deficiency.

There were 6 cases of macrocytic anaemia, of which were most probably caused by Vitamin B12 or Folate deficiency. Similar results were seen in a study by Rairikar et $\mathrm{al}^{4}$ and Walker et al. ${ }^{16}$

\section{CONCLUSION}

There is a high prevalence of anaemia emerging as a global public health problem in both the developed and developing countries, which poses serious consequences in the human socioeconomic health and development. So, by performing a thorough evaluation of blood cell indices and their correlation with red cell distribution pattern, reticulocyte count and peripheral smear examination will help the primary physicians to reach a diagnosis without the need of special and costly investigations.



\begin{tabular}{|c|c|c|c|c|c|c|}
\hline \multicolumn{7}{|c|}{ Category of Anaemia } \\
\hline & 1 & 2 & 3 & 4 & 5 & 6 \\
\hline $\begin{array}{l}\text { C } \\
\text { A } \\
\text { U } \\
\text { S } \\
\text { E } \\
\text { S }\end{array}$ & $\begin{array}{l}\text { a) Heterozygous } \\
\text { thalassemia } \\
\text { b) Chronic disease }\end{array}$ & $\begin{array}{l}\text { a) Iron deficiency } \\
\text { anaemia } \\
\text { b) B-thalassemia } \\
\text { c) Haemoglobin-H } \\
\text { d) Red cell } \\
\text { fragmentation }\end{array}$ & $\begin{array}{c}\text { a) Normal } \\
\text { b) Chronic disease } \\
\text { c) Chronic liver disease } \\
\text { d) Non-anaemic } \\
\text { haemoglobinopathy } \\
\text { e) Transfusion } \\
\text { f) Chemotherapy } \\
\text { g) CLL } \\
\text { h) CML } \\
\text { i) Hereditary } \\
\text { spherocytosis }\end{array}$ & $\begin{array}{l}\text { a) Mixed deficiency } \\
\text { b) Early iron or folate } \\
\text { deficiency } \\
\text { c) Anaemic } \\
\text { haemoglobinopathy } \\
\text { d) Myelofibrosis } \\
\text { e) Sideroblastic }\end{array}$ & $\begin{array}{l}\text { a) Aplastic anaemia } \\
\text { b) Pre-leukaemia }\end{array}$ & \begin{tabular}{|} 
a) Folate or \\
Vitamin B-12 \\
deficiency \\
b) Immune \\
haemolytic \\
anaemia \\
c) Cold \\
agglutinin \\
d) CLL
\end{tabular} \\
\hline & & & Table 2 & & & \\
\hline
\end{tabular}

1. Microcytic homogeneous (MCV- Low, RDW- Normal)

2. Microcytic heterogeneous (MCV- Low, RDW- High)

3. Normocytic homogeneous (MCV- Normal, RDWNormal)

4. Normocytic heterogeneous (MCV- Normal, RDW- High)

5. Macrocytic homogeneous (MCV- High, RDW- Normal)

6. Macrocytic heterogeneous (MCV- High, RDW- High)

\section{REFERENCES}

[1] Milman N. Anaemia-still a major problem in many parts of the world. Ann Haematol 2011;90(4):369-77.

[2] WHO. The prevalence of anaemia in women: a tabulation of available information. 2nd edn. Geneva, Switzerland, 1992. WHO/MCH/MSM/92.2

[3] Bansal A, Sharma AK, Sharma A, et al. Iron deficiency anaemia in women of reproductive age group attending a tertiary care hospital. Indian J Sci Res 2016;7(1):109-13.

[4] Rairikar SS, Ahire AP, Baheti NR, et al. A study of blood cell indices and reticulocyte count in cases of anaemia in females in reproductive age group. MVP Journal of Medical Sciences 2014;1(2):56-60.
[5] Glader BGM. Wintrobe's Clinical haematology. 12th edn. Philadelphia: Wolters Kluwer Company 2009.

[6] Bhatia V, Mishra B, Manandhar N, et al Prevalence of anaemia among females of the reproductive age group visiting Chisapani Dispensary. Journal of the Institute of Medicine 1999;21:1-235.

[7] Sharma V, Sahni B, Jamwal DS, et al. Nutritional anaemia among currently married females in the reproductive age group in rural Jammu. Journal of Evolution of Medical and Dental Sciences 2013;2(42):8176-85.

[8] Mukhopadhyay AK, Salam SR. The basics of blood cell counter. Laboratory Diagnosis 1993;1(4):17-22.

[9] World Health Organisation. Control of Nutritional anaemia with special reference to iron deficiency. Technical report series No. 580, 1975.

[10] Mehta BC. Iron deficiency amongst nursing students. Indian J Med Sci 2004;58(9):389-93.

[11] National Family Health Surveillance-3. Nutrition and Anaemia. 2005-06;1:267-313. 
[12] Viswanath D, Hegde R, Murthy V, et al. Red cell distribution width in the diagnosis of iron deficiency anaemia. Ind J of Paediatric 2001;68(12):1117-9.

[13] Carmen SPL, Aparecida RCR, Helena ZWG, et al. Comparison of red cell distribution width and red cell discriminant function incorporating volume dispersion for distinguishing iron deficiency from beta thalassemia trait in patients with microcytosis. Sau Paulo Med Journal 1996;114(5):1265-9.
[14] Beutler E. The red cell indices in the diagnosis of iron deficiency anaemia. Ann Internal Med 1959;50(2):313-22.

[15] Bessman JD, Gilmer PR Jr, Gardner FH. Improved classification of anaemia by MCV and RDW. Am J Clin Pathol 1983;80(3):322-6.

[16] Walker K, Dallas W, Hurst JW. Red cell indices: clinical methods. 3rd edn. Boston: NCBI Bookshelf Butterworth Publisher 1990. 